\title{
UJI PATOGENISITAS JAMUR Beauveria bassiana YANG DIISOLASI DARI Hypothenemus hampei PADA Sitophilus oryzae DI TINGKAT LABORATORIUM
}

\author{
Yosua Adi Aeng Raya, I Gede Swibawa \& Indriyati \\ Jurusan Agroteknologi, Fakultas Pertanian Universitas Lampung \\ Jl. Prof. Soemantri Brodjonegoro, No. 1, Bandar Lampung 35145 \\ E-mail: raya.yosua@yahoo.co.id
}

\begin{abstract}
ABSTRAK
Dampak negatif pestisida yang merugikan kesehatan masyarakat dan lingkungan hidup mendorong berkembangnya pengendalian hama secara hayati. Pengendalian hama menggunakan musuh alami, seperti jamur patogen serangga diketahui efektif dan aman bagi lingkungan. Salah satu spesies jamur patogen serangga yang potensial sebagai agen pengendali hayati hama adalah Beauveria bassiana Balsamo. Penelitian ini bertujuan untuk menguji patogenisitas jamur entomopatogen $B$. bassiana yang diisolasi dari hama penggerek buah kopi sakit terhadap Sitophilus oryzae. Pengujian terpisah dilakukan di laboratorium, yaitu pengujian isolat jamur dari Lampung Barat dan isolat dari Tanggamus, menggunakan 4 perlakuan dan 5 ulangan yaitu kontrol (akuades), suspensi jamur pada tingkat pengenceran $10^{-2}, 10^{-3}$, dan $10^{-4}$. Satuan percobaan yaitu 20 individu kumbang $S$. oryzae disusun menggunakan Rancangan Acak Lengkap (RAL). Hasil penelitian menunjukkan bahwa daya patogenisitas jamur $B$. bassiana pada $S$. oryzae masih rendah. Persentase mortalitas S.oryzae sebesar $52 \%$ tersebab $B$.

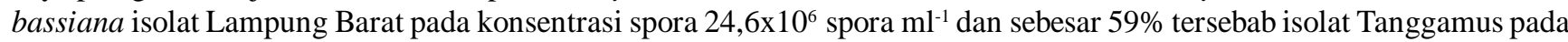
konsentrasi spora $64,8 \times 10^{6}$ spora $\mathrm{ml}^{-1}$. Periode letal serangga uji terinfeksi B. bassiana isolat Lampung Barat yaitu 5,38 hari dengan virulensi 0,24 pada konsentrasi spora $24,6 \times 10^{6}$ spora $\mathrm{ml}^{-1}$ dan pada isolat Tanggamus yaitu 7,42 hari dengan virulensi

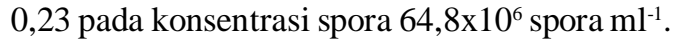

Kata Kunci: Beauveria bassiana, Patogenisitas, Sitophilus oryzae.

\section{PENDAHULUAN}

Dampak negatif pestisida yang merugikan kesehatan masyarakat dan lingkungan hidup semakin lama semakin menonjol. Selain itu, penggunaan pestisida juga menyebabkan resistensi, resurgensi, dan peledakan hama sekunder (Untung, 1993). Dampak negatif inilah yang mendorong berkembangnya pengendalian hayati, yaitu pengendalian hama dengan menggunakan musuh alami. Salah satu spesies jamur patogen serangga yang potensial sebagai pengendali beberapa spesies serangga hama adalah Beauveria bassiana Balsamo. Cendawan ini dilaporkan sebagai agensia hayati yang sangat efektif mengendalikan sejumlah spesies serangga hama termasuk rayap, kutu putih, dan beberapa jenis kumbang (Gillespie, 1988 dalam Soetopo dan Indrayani, 2007).

Dari hasil penelitian Maharani (2013), keberadaan jamur patogen serangga dalam perkebunan kopi mampu menyebabkan penyakit pada hama penggerek buah kopi (Hypothenemus hampei). Persentase keterjadian penyakit pada hama PBKo yang ditemukan pada buah kopi rusak bertanda adanya infeksi jamur di Sumberjaya, Lampung Barat mencapai 45,79 \% pada kebun agroforestri kompleks dan sebesar 27,23\% pada kebun agroforestri sederhana. Jamur patogen yang menginfeksi
PBKo ini memiliki ciri yang mirip dengan Beauveria bassiana.

Jamur B. bassiana yang ditemukan dari PBKo tersebut perlu dipelajari lebih lanjut. Hal ini dilakukan agar dapat diketahui keefektifan setiap isolat jamur yang ditemukan. Oleh karena itu, maka dalam penelitian ini dilakukan uji patogenisitas isolat B.bassiana yang diisolasi dari $H$. hampei pada serangga uji $S$. oryzae. Dengan penelitian ini diharapkan dapat diketahui daya patogenisitas $B$. bassiana yang diisolasi dari $H$. hampei Penelitian ini bertujuan untuk menguji patogenisitas jamur B. bassiana yang diisolasi dari $H$. hampei pada $S$. oryzae di tingkat laboratorium.

\section{BAHAN DAN METODE}

Penelitian dilaksanakan di Laboratorium Penyakit Tumbuhan Fakultas Pertanian Universitas Lampung. Perbanyakan isolat jamur B. bassiana dilaksanakan pada bulan Juni 2012 sampai Agustus 2012, dan aplikasinya pada bulan September sampai Oktober 2012.

Pada penelitian ini digunakan 2 jenis isolat $B$. bassiana, yaitu isolat Lampung Barat dan Tanggamus. Setiap isolat diujikan pada serangga $S$. oryzae secara terpisah. Setiap set percobaan disusun dalam rancangan 
acak lengkap (RAL) yang terdiri dari 4 perlakuan dan 5 ulangan. Perlakuan yang dicobakan adalah tingkat kerapatan spora yang diperoleh dengan membuat suspensi jamur pada tingkat pengenceran $10^{-2}, 10^{-3}, 10^{-4}$, dan kontrol (akuades). Sebagai satuan percobaan adalah 20 ekor kumbang bubuk beras $S$. oryzae (Coleoptera: Curculionidae), yang dipelihara pada beras. Kumbang bubuk beras didapatkan dari beras yang sudah lama tersimpan. Kumbang dibiakkan pada beras dalam toples berukuran besar (diameter $30 \mathrm{~cm}$ ).

Inokulum B. bassiana yang diisolasi dari serangga penggerek bubuk buah kopi (H. hampei) sakit berasal dari perkebunan kopi di daerah Sumberjaya Lampung Barat dan Tanggamus. Jamur yang telah dimurnikan dipindahkan ke cawan petri yang telah diisi SDA dan ditumbuhkan selama 2 minggu hingga mencapai pertumbuhan penuh. Jamur dipanen dan dipisahkan dari media SDA, kemudian dipindahkan ke dalam tabung reaksi yang berisi aquades $9 \mathrm{ml}$, kemudian di rotary mixer selama 1 menit. Tahap ini menghasilkan tingkat pengenceran $10^{-1}$, selanjutnya pengenceran $10^{-2}$ dilakukan dengan cara mengambil sebanyak $1 \mathrm{ml}$ suspensi $10^{-1}$ dipindahkan ke dalam tabung reaksi yang berisi $9 \mathrm{ml}$ akuades. Demikian seterusnya dengan tahapan yang sama untuk mendapatkan tingkat pengenceran $10^{-3} \mathrm{dan} 10^{-4}$.

Kerapatan spora untuk tiap tingkat pengenceran dihitung menggunakan Haemocytometer di bawah mikroskop majemuk pada perbesaran $400 \mathrm{x}$. Kerapatan spora per ml dihitung dengan menggunakan rumus Gabriel \& Riyatno (1989) sebagai berikut :

$$
C=\frac{t}{N \times 0,25} \times 10^{6}
$$

Keterangan :

$\mathrm{C}=$ kerapatan spora per ml larutan

$\mathrm{t} \quad=$ jumlah total spora dalam kotak sampel yang diamati

$\mathrm{N}=$ jumlah kotak sampel yang diamati

$0,25=$ merupakan faktor koreksi penggunaan kotak sampel skala kecil dalam Haemocytometer.

Suspensi B. bassiana diaplikasikan dengan menggunakan metode semprot. Serangga uji diletakkan dalam wadah dan disemprot dengan $5 \mathrm{ml}$ suspensi patogen sesuai perlakuan tingkat pengenceran. Pada perlakuan kontrol serangga hanya disemprot dengan aquades. Serangga yang telah disemprot dibiarkan tergenang dalam suspensi selama \pm 5 detik, kemudian diletakkan di permukaan tissue. Serangga yang telah diberi perlakuan, diberikan pakan beras. Pengamatan dilakukan setiap hari untuk melihat tanda adanya infeksi patogen yaitu serangga menjadi sakit dengan menunjukan gejala tidak aktif bergerak. Serangga uji yang terindikasi sakit dikeluarkan dan ditempatkan pada wadah yang berbeda dan perkembangannya diamati setiap hari sampai mati.

Peubah patogenisitas yang diamati meliputi tingkat mortalitas, periode letal dan tingkat virulensi. Tingkat mortalitas dihitung dengan menggunakan rumus :

Tingkat mortalitas $=\frac{\text { Jumlah serangga mati }}{\text { Jumlah seluruh serangga }} \times 100 \%$

Periode letal dan tingkat virulensi $B$. bassiana, dihitung dengan menggunakan rumus Susilo (1993 dalam Indriyati 2009):

$$
\begin{aligned}
& \text { Periodeletal }(F)=\frac{\sum(H i)(M i)}{\sum M i} \\
& \text { Tingkat virulensi }(\delta)=\frac{1}{F}
\end{aligned}
$$

Keterangan :

$$
\begin{array}{ll}
\mathrm{Hi} & =\text { Waktu kematian } \\
\mathrm{Mi} & =\text { Jumlah serangga yang mati terinfeksi }
\end{array}
$$

Data hasil pengamatan dianalisis ragam dan dilanjutkan dengan uji pemisahan nilai tengah menggunakan uji BNT. Semua analisis statistik menggunakan taraf nyata $5 \%$ atau $1 \%$.

\section{HASIL DAN PEMBAHASAN}

Hasil analisis ragam menunjukkan bahwa perlakuan B. bassiana isolat Lampung Barat berpengaruh nyata terhadap mortalitas $S$. oryzae. Uji BNT menunjukkan bahwa perlakuan pengenceran $10^{-3}$ atau $24,6 \times 10^{6}$ spora $\mathrm{ml}^{-1}$ menyebabkan mortalitas $52 \%$ yang lebih tinggi dibanding mortalitas pada perlakuan pengenceran $10^{-2}$ atau $10,8 \times 10^{7}$ spora $\mathrm{ml}^{-1}$ dan $10^{-4}$

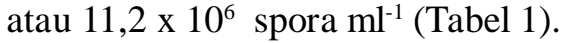

Dari hasil analisis ragam diketahui bahwa perlakuan $B$. bassiana isolat Lampung Barat memberikan pengaruh yang sangat nyata terhadap periode letal $S$. oryzae. Uji BNT menunjukkan bahwa pada perlakuan pengenceran $10^{-2}$ atau $10,8 \times 10^{7}$ spora $\mathrm{ml}^{-1}$ menyebabkan periode letal yaitu 5,38 hari, lebih cepat dibandingkan dengan periode letal pada perlakuan pengenceran $10^{-3}$ atau $24,6 \times 10^{6}$ spora $\mathrm{ml}^{-1}$ yaitu 11,52 hari, dan perlakuan pengenceran $10^{-4}$ atau $11,2 \times 10^{6}$ spora $\mathrm{ml}^{-1}$ yaitu 10,15 hari. Kedua periode letal yang disebut terakhir ini tidak berbeda nyata (Tabel 1). Analisis ragam, 
Tabel 1. Mortalitas dan periode letal S. oryzae serta virulensi B. bassiana isolat Lampung Barat.

\begin{tabular}{lccc}
\hline Konsentrasi & Mortalitas (\%) & Periode Letal (hari) & Virulensi(\%) \\
\hline Kontrol & $27 \mathrm{~b}$ & $0 \mathrm{c}$ & $0 \mathrm{c}$ \\
$10^{-2}$ atau $10,8 \times 10^{-7}$ & $31 \mathrm{~b}$ & $5,38 \mathrm{a}$ & $0,24 \mathrm{a}$ \\
$10^{-3}$ atau $24,6 \times 10^{-6}$ & $52 \mathrm{a}$ & $11,52 \mathrm{~b}$ & $0,09 \mathrm{~b}$ \\
$10^{-4}$ atau $11,2 \times 10^{-6}$ & $29 \mathrm{~b}$ & $10,15 \mathrm{~b}$ & $0,15 \mathrm{ab}$ \\
\hline F hitung & $4,32 *$ & $15,19 * *$ & $4,71 *$ \\
\hline
\end{tabular}

Keterangan : Angka yang diikuti huruf sama pada kolom yang sama menunjukkan tidak berbeda nyata menurut uji BNT pada $\alpha_{0,01}$ atau $\alpha_{0,05}{ }^{*} * *$ atau $*$ = berbeda nyata menurut uji $\mathrm{F}$ pada $\alpha_{0,01}$ atau $\alpha_{0,05}$.

menunjukkan bahwa perlakuan B. bassiana berpengaruh sangat nyata terhadap virulensi $B$. bassiana isolat Lampung Barat pada $S$. oryzae. Uji BNT menunjukkan bahwa $B$. bassiana isolat Lampung Barat pada perlakuan pengenceran $10^{-2}$ atau $10,8 \times 10^{7}$ spora $\mathrm{ml}^{-1}$ memiliki virulensi sebesar 0,24 . Virulensi pada pengenceran $10^{-2}$ ini lebih tinggi dibandingkan dengan virulensi pada perlakuan pengenceran $10^{-3}$ atau $24,6 \times 10^{6}$ spora $\mathrm{ml}^{-1}$ yaitu sebesar 0,09 , tetapi besar virulensi ini tidak berbeda dengan virulensi pada pengenceran $10^{-4}$ atau $11,2 \times 10^{6}$ spora $\mathrm{ml}^{-1}$ yaitu sebesar 0,15 (Tabel 1 ).

Untuk isolat Tanggamus, hasil analisis ragam menunjukkan bahwa perlakuan $B$. bassiana nyata mempengaruhi mortalitas $S$. oryzae. Uji BNT menunjukkan bahwa perlakuan $B$. bassiana pada pengenceran $10^{-3}$ atau $64,8 \times 10^{6}$ spora $\mathrm{ml}^{-1}$ menyebabkan mortalitas paling tinggi yaitu 59\% dibandingkan dengan mortalitas pada perlakuan lainnya. Perlakuan pengenceran $10^{-2}$ atau $11,52 \times 10^{7}$ spora $\mathrm{ml}^{-1}$ dan $10^{-4}$ atau $27,2 \times 10^{6}$ spora $\mathrm{ml}^{-1}$ menyebabkan mortalitas masingmasing $39 \%$ dan $46 \%$, kedua tingkat mortalitas ini tidak berbeda nyata (Tabel 2).

Analisis ragam juga menunjukkan bahwa perlakuan B. bassiana berpengaruh sangat nyata terhadap periode letal $S$. oryzae. Uji BNT menunjukkan bahwa periode letal pada semua tingkat pengenceran suspensi $B$. bassiana tidak berbeda kecuali dengan kontrol. Periode letal $S$. oryzae berkisar 7,4 - 8,5 hari (Tabel 2).

Selain itu dari hasil analisis ragam juga menunjukkan bahwa perlakuan $B$. bassiana berpengaruh nyata terhadap virulensi $B$. bassiana pada $S$. oryzae. Uji BNT menunjukkan bahwa perlakuan pengenceran $10^{-2}$ atau $11,52 \times 10^{7}$ spora $\mathrm{ml}^{-1}$ menyebabkan virulensi jamur patogen uji tinggi mencapai 0,23 . Virulensi tersebut lebih tinggi dibanding dengan virulensi pada perlakuan pengenceran $10^{-3}$ atau $64,8 \times 10^{6}$ spora $\mathrm{ml}^{-1}$ dan perlakuan pengenceran $10^{-4}$ atau $27,2 \times 10^{6}$ spora $\mathrm{ml}^{-1}$ dengan virulensi masing-masing sebesar 0,14 dan 0,13 (Tabel 2). Pada Tabel 1 dan 2, tampak bahwa peningkatan kerapatan spora tidak diikuti oleh peningkatan mortalitas serangga uji baik untuk isolat Lampung Barat maupun Tanggamus. Hal tersebut dapat dilihat dari persentase kematian tertinggi terjadi pada perlakuan pengenceran $10^{-3}$ dengan kerapatan spora

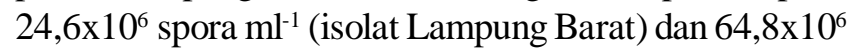
spora $\mathrm{ml}^{-1}$ (isolat Tanggamus). Selain itu, pada kontrol juga didapati serangga yang mati. Diduga pengaruh metode aplikasi yang kurang tepat dan umur $S$. oryzae yang tidak seragam di setiap satuan percobaan menyebabkan mortalitas tidak konsisten dalam penelitian ini. Diduga persentase mortalitas setiap serangga uji berkaitan dengan daya tahannya terhadap patogen. Jumlah serangga yang rentan pada satuan percobaan mempengaruhi persentase mortalitas pada perlakuan tersebut.

Dari Tabel 1 pada data periode letal B. bassiana Lampung Barat pada konsentrasi $10^{-2}$ dengan kerapatan spora $10,8 \times 10^{7}$ spora $\mathrm{ml}^{-1}$ menyebabkan periode letal pada $S$. oryzae paling singkat. Sedangkan dari Tabel 2 untuk isolat Tanggamus periode letal paling singkat terjadi pada konsentrasi $10^{-3}$ atau $64,8 \times 10^{6}$ spora $\mathrm{ml}^{-1}$. Periode letal pada $S$. oryzae ini, tidak jauh berbeda dengan periode letal kepik hijau dan kutu daun yang diberi perlakuan B. bassiana isolat PT GMP dan BVR komersil yaitu masing-masing 5,44 dan 4,58 hari untuk kepik hijau dan masing-masing 3,70 dan 3,72 hari untuk kutu daun (Indriyati, 2009). Dari informasi ini terdapat indikasi bahwa jamur patogen serangga $B$. bassiana menyebabkan periode letal yang berbeda tergantung jenis serangga uji.

Pada Tabel 1 dan 2 terlihat bahwa pada pengenceran $10^{-2}$, tingkat virulensi jamur uji lebih tinggi jika dibanding dengan virulensi pada konsentrasi yang lain. Hal ini disebabkan oleh jumlah spora yang terdapat pada pengenceran $10^{-2}$ lebih banyak daripada pengenceran yang lain. Virulensi tergantung pada jumlah patogen pada serangga inang. Patogen yang mempunyai virulensi tinggi biasanya memiliki masa inkubasi yang pendek dan dapat membunuh inangnya 
Tabel 2. Mortalitas dan periode letal S. oryzae serta virulensi B. bassiana isolat Tanggamus.

\begin{tabular}{lccc}
\hline Konsentrasi & Mortalitas $(\%)$ & Periode Letal (hari) & Virulensi(\%) \\
\hline Kontrol & $32 \mathrm{c}$ & $0 \mathrm{~b}$ & $0 \mathrm{c}$ \\
$10^{-2}$ atau $11,52 \times 10^{-7}$ & $39 \mathrm{bc}$ & $8,46 \mathrm{a}$ & $0,23 \mathrm{a}$ \\
$10^{-3}$ atau $64,8 \times 10^{-6}$ & $59 \mathrm{a}$ & $7,42 \mathrm{a}$ & $0,14 \mathrm{~b}$ \\
$10^{-4}$ atau $27,2 \times 10^{-6}$ & $46 \mathrm{~b}$ & $8,51 \mathrm{a}$ & $0,13 \mathrm{~b}$ \\
\hline F hitung & $4,79 *$ & $6,19 * *$ & $3,65 *$ \\
\hline
\end{tabular}

Keterangan : Angka yang diikuti huruf sama pada kolom yang sama menunjukkan tidak berbeda nyata menurut uji BNT pada $\alpha_{0,01}$ atau $\alpha_{0,05^{*}} * *$ atau $*$ = berbeda nyata menurut uji F pada $\alpha_{0,01}$ atau $\alpha_{0,05^{*}}$

dengan cepat (Tanada dan Kaya, 1993). Dari hasil penelitian ini, diperoleh informasi bahwa virulensi yang tinggi disertai periode letal yang singkat tidak serta merta diikuti persentase mortalitas serangga uji yang tinggi pula. Sebab virulensi dan periode letal itu diduga berkaitan dengan karakter biologi suatu jamur patogen. Sedangkan mortalitas serangga uji berkaitan dengan ketahanan serangga itu sendiri terhadap suatu patogen.

\section{KESIMPULAN}

Beberapa kesimpulan dapat ditarik dari hasil penelitian ini diantaranya adalah daya patogenisitas jamur B. bassiana isolat Lampung Barat dan Tanggamus pada $S$. oryzae masih rendah. Persentase mortalitas $S$. oryzae sebesar $52 \%$ tersebab B. bassiana isolat Lampung Barat pada konsentrasi spora 24,6×10 $10^{6}$ spora $\mathrm{ml}^{-1}$ dan $59 \%$ tersebab isolat Tanggamus pada konsentrasi spora $64,8 \times 10^{6}$ spora $\mathrm{ml}^{-1}$. Periode letal serangga uji terinfeksi $B$. bassiana isolat Lampung Barat yaitu 5,38 hari dengan virulensi 0,24 pada konsentrasi spora $24,6 \times 10^{6}$ spora $\mathrm{ml}^{-1}$ dan pada isolat Tanggamus yaitu 7,42 hari dengan virulensi 0,23 pada konsentrasi spora $64,8 \times 10^{6}$ spora $\mathrm{ml}^{-1}$.

\section{SANWACANA}

Penelitian ini merupakan bagian dari proyek penelitian dosen yang didanai oleh Dikti melalui dana Hibah Bersaing. Untuk itu, dalam kesempatan ini penulis mengucapkan terima kasih kepada bapak Dr. Ir. Hamim Sudarsono, M.Sc. selaku ketua peneliti.

\section{DAFTAR PUSTAKA}

Gabriel, B.P. \& Riyanto. 1989. Metarhizium anisopliae Taksonomi, Patologi, Produksi dan Aplikasinya. Proyek Pengembangan Perlindungan Tanaman Perkebunan. Direktorat Perlindungan Tanaman Perkebunan. Departemen Pertanian. Jakarta. $25 \mathrm{hlm}$.

Indriyati. 2009. Virulensi jamur entomopatogen Beauveria bassiana (Balsamo) Vuillemin (Deuteromycotina: Hyphomycetes) terhadap kutu daun (Aphis spp.) dan kepik hijau (Nezara viridula). Jurnal HPT Tropika, 9 (2): 92-98.

Maharani, J.S. 2013. Keterjadian Penyakit Tersebab Jamur Pada Hama Penggerek Buah Kopi (Pbko) di Pertanaman Kopi Agroforestri. Skripsi. Fakultas Pertanian. Universitas Lampung. Bandar Lampung. $56 \mathrm{hlm}$.

Soetopo, D. \& Indrayani, I. 2007. Status Teknoogi dan Prospek Beauveria bassiana Untuk Pengendalian Serangga Hama Tanaman Perkebunan Yang Ramah Lingkungan. Balai Penelitian Tanaman Tembakau dan Serat. Malang. $18 \mathrm{hlm}$.

Tanada, Y. \& Kaya, H.K.. 1993. Insect Pathology. Academic Press. New York. 666 hlm.

Untung, K. 1993. Pengantar Pengelolaan Hama Terpadu. UGM Press, Yogyakarta. $273 \mathrm{hlm}$. 